\author{
Natalia Drop \\ Faculty of Economics and Transport Engineering, Maritime University of Szczecin

\section{AIRBUS' ELECTRICALLY POWERED AIRCRAFT AS AN ANSWER TO THE EUROPEAN UNION'S LOW-CARBON POLICY}

\begin{abstract}
Air transport is currently the fastest developing branch of transport, and airlines get to carry more and more passengers and cargo every year. At the same time, societies are more aware of environmental damage caused by transport, which is why the European Parliament developed a document titled An Aviation Strategy for Europe, which points out actions that should be taken in order to make air transport more environmentally-friendly. One of the assumptions is to reduce the greenhouse gas' emission. The European Parliament suggests the use of biofuels as one of possible solutions to reduce the negative impact that air transport has on the natural environment. However, airplane manufacturers come up with different ideas how to reduce emission. Airbus in cooperation with Siemens and Rolls-Royce are working on an electrically powered aircraft. The project they are working on is called E-Fan X and it involves replacing one of airplane's four turbine engines with an electric motor with a capacity of $2 \mathrm{MW}$. The first tests are to be performed next year. The paper describes the idea developed by Airbus, points out its advantages and disadvantages, and forecasts what impact the appearance of electrically powered aircraft will have on the environment and airline industry. The paper will be based on author's own knowledge and gathered materials, and also on literature analysis, deduction and empirical research using non-experimental methods.
\end{abstract}

Keywords: air transport, sustainable transport, electrically powered airplane, Airbus

JEL: Q5 


\section{Introduction}

Air transport is one of the fastest developing branches of transport. Short travel time, high availability, high level of safety and relatively low ticket prices have changed people's view on air transport. Journeys by air stopped being considered as a luxury and a latent demand had been awoken. This means that some people, who have never travelled before, started to do it and others decided to choose air transport to different branches. This development had positive impact on economy, but unfortunately negative on environment. More people traveling means more planes in the air, and more planes in the air means higher emission. To slow down degradation of the environment, the European Commission developed a document entitled An Aviation Strategy for Europe, where actions that should be taken in order to lower the negative impact air transport has on the natural environment are pointed out.

In response to the European Union's policy, aviation companies started working on solutions that would make airplanes more environmentally-friendly. The European Commission's suggestion is to convert air transport to biofuels, but Airbus came up with a different idea to lower emissions. Airbus with cooperation with Siemens and Rolls-Royce proposed to convert airplanes to electric drive. The project they're currently working on is called E-Fan X and the idea is to replace one of four turbine engines with an electric one.

The paper is intended to present the background for quick growth in the field of air transport and describe the concept of E-Fan X and foresee what impact it will have on the environment and the whole aviation market.

\section{Theoretical and historical background}

Quick development of air transport on the European market began in the 1980's when open-sky agreements came into force. The main aim of these agreements was (Ruciński, 2008):

- to help to establish new enterprises;

- to allow carriers to set routes freely;

- to allow carriers to freely set transport rates;

- to allow carriers to freely set terms and conditions of carriage;

- to allow carriers to set transport volume freely;

- to allow carriers to freely choose ticket distribution channels and conditions.

Such regulations led to establishment of companies whose operating philosophy is based on maximum cost reduction - low-cost air carriers (LCC's). Reducing operating costs to minimum allowed reducing ticket prices. This forced national (or traditional) air carriers to fix their strategies and also apply the strategy focused on maximum cost reduction.

Quick expansion of LCC's had a positive impact on the economic feature of passenger air transport market and led to an increase in the number of passengers carried annually (Figure 1$)^{1}$.

1 Data source: Eurostat website, http://ec.europa.eu/eurostat. 
1200000000

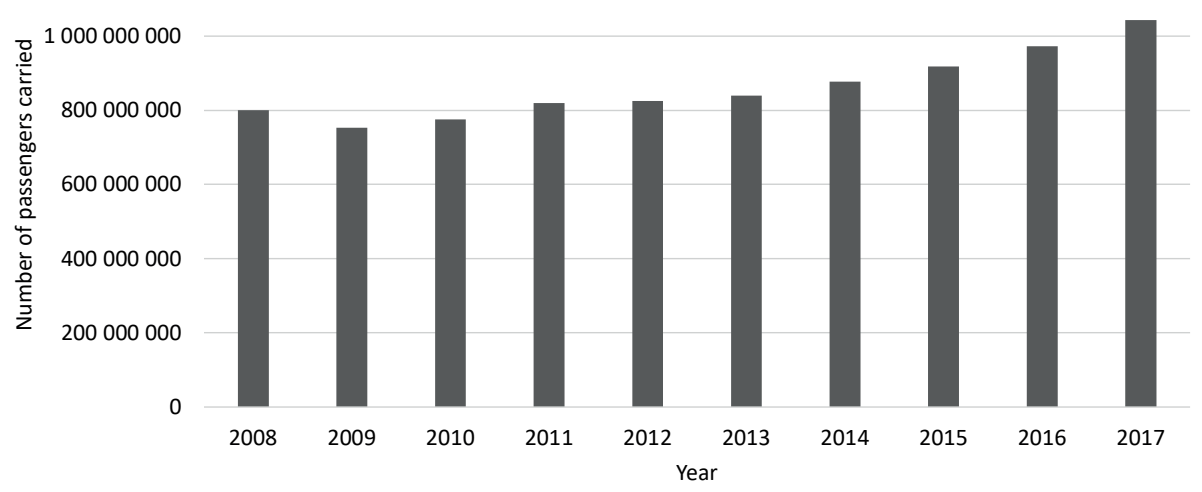

Figure 1. Number of passengers carried annually in the European Union by air transport by year (2008-2017)

Source: (own elaboration based on data from: http://ec.europa.eu/eurostat [Accessed 2 April 2019])

On the other hand - growth in the number of air journeys means higher negative impact on the environment. It is expected that global air transport volume will increase by $5 \%$ yearly until 2030, what will lead to an overall growth of $150 \%$ (Tłoczyński, 2013). A rise in the number of journeys causes a higher demand on airplanes. Changes in the volume of commercial airplane fleet on the European market is shown in Figure $2^{2}$.

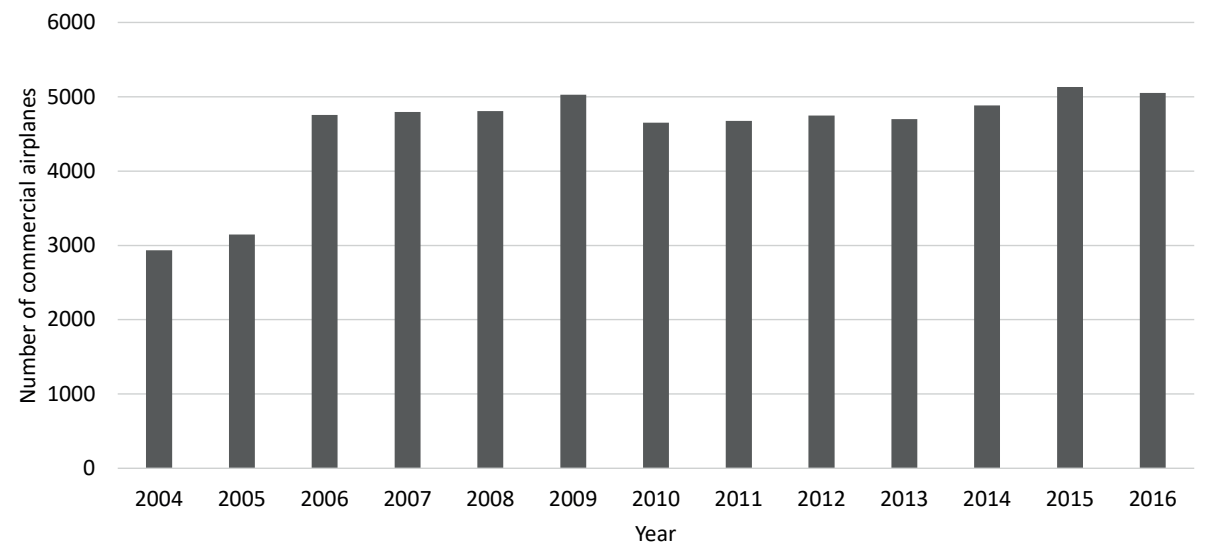

Figure 2. Volume of commercial aircraft fleet in Europe by year (2004-2016)

Source: (own elaboration based on data from: http://ec.europa.eu/eurostat [Accessed 02 April 2019])

A greater number of airplanes in the air leads to higher emission of greenhouse gas, such as $\mathrm{CO}_{2}, \mathrm{NO}_{x}$ and $\mathrm{SO}_{x}$. Yearly changes of emission in millions of tones based on data gathered by the European Environment Agency are presented in Figure

2 Data source: Eurostat website, http://ec.europa.eu/eurostat. 
$3^{3}$. The numbers show that the level of global emission from air transport reaches nearly 150 million tons a year (http://lot.com) and it is expected to be ten times higher in 2050 (Tłoczyński, 2013). To raise awareness of the scale of the problem, the International Civil Aviation Organization (ICAO) created a calculator that calculates the amount of carbon dioxide per passenger on a chosen route (http:// icao.int).

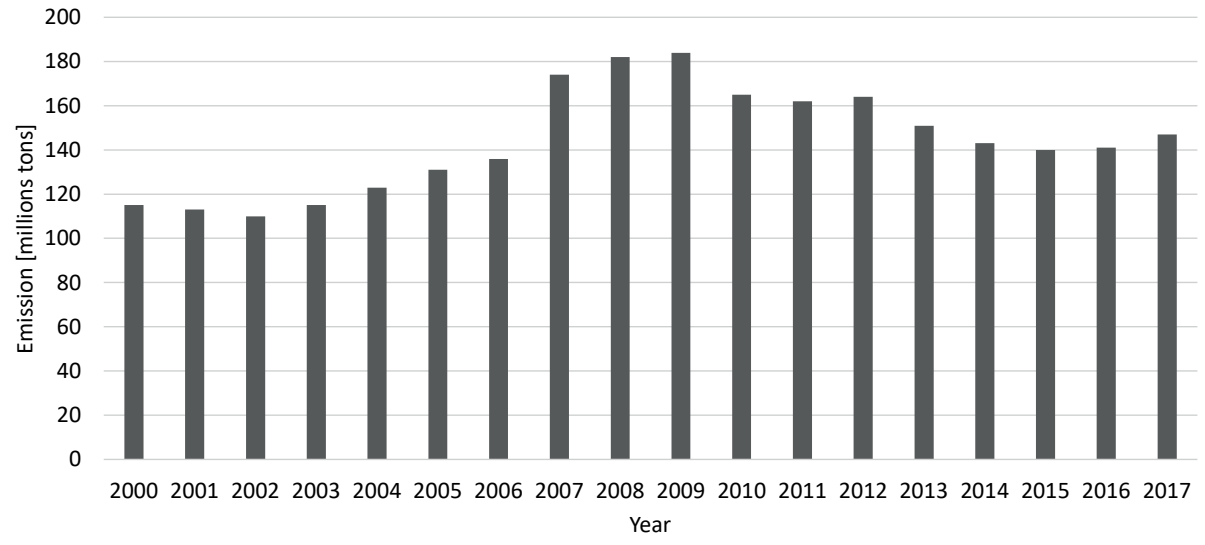

Figure 3. Global emission of greenhouse gas by year (2000-2017)

Source: (own elaboration based on data from: http://ec.europa.eu/eurostat [Accessed 2 April 2019])

Being aware of the negative impact air transport has on natural environment, the European Union's authorities have begun to put more pressure on the sustainable development of transport. Sustainable transport is, above all, low-carbon, safe and energy saving. At the same time, however, it has to be economically efficient, cheap, highly available and varied. This forces carriers and airplane manufacturers to develop new technical, technological and organizational solutions that will allow to meet high demands set by the sustainable development policy (Figure 4).

This is why the European Commission created a document titled An Aviation Strategy for Europe in which the Commission points out actions which should be taken to make air transport more environmentally friendly. At the beginning it is noted that aviation sector enterprises should simultaneously pay attention to keeping high level of competitiveness and caring for the environment. All companies must keep high environmental standards in order to meet demand of sustainable transport and to decrease the negative impact on ecosystems. European Union itself has also prepared regulations for transport in general, but they may also be applied by air transport sector. The aim of these regulations is to reduce greenhouse gas emissions. The Commission also suggests that the EU should cooperate with other regions in order to make homogenous global regulations for carbon-neutral development of air transport markets and airplanes manufacturing. Another suggestion by the European Commission for making air transport more "green" is the use of biofuels that is supposed to lead to a reduction in the use of conventional fuels.

\footnotetext{
3 Data source: European Environment Agency (EEA) website, http://eea.europa.eu.
} 
Some companies follow this idea, while others are searching for different solutions, and Airbus is such a company. Instead of using biofuels, Airbus intends to replace conventional fuel with electricity.

\section{Sustainable transport}

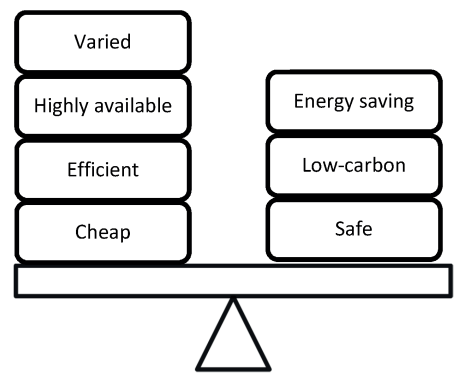

Figure 4. Features of sustainable transport

Source: (Kotowska, 2014)

\section{E-Fan $X$ hybrid aircraft}

Since the EU wishes for $75 \%$ reduction of $\mathrm{CO}_{2}$ emission, $90 \% \mathrm{NO}_{x}$ emission and 65\% noise emission by 2050 (Airbus, Rolls-Royce, Siemens, 2017), Airbus, Siemens and Rolls-Royce have joined their forces to build a machine that would meet these expectations. The idea is to replace one of four turbofans of Airbus Bae 146 airplane with an electric motor, with a prospect of replacing another one in the future (Figure 5). The segregation of duties is such (Airbus, Rolls-Royce, Siemens, 2017) (Figure 6):

- Siemens is responsible for the design of the electric motor, its control unit and systems of power distribution;

- Rolls-Royce will fit the motor and fan into the nacelle and adapt all power electronics and cooling system;

- Airbus is responsible for integration of all systems.

Biggest challenges that stand in the way of Airbus E-Fan X project are (Airbus,

Rolls-Royce, Siemens, 2017):

- altitude;

- temperature;

- thrust management;

- electromagnetic compatibility.

First tests of the prototype aircraft equipped in the E-Fan X motor are planned for 2020 . 


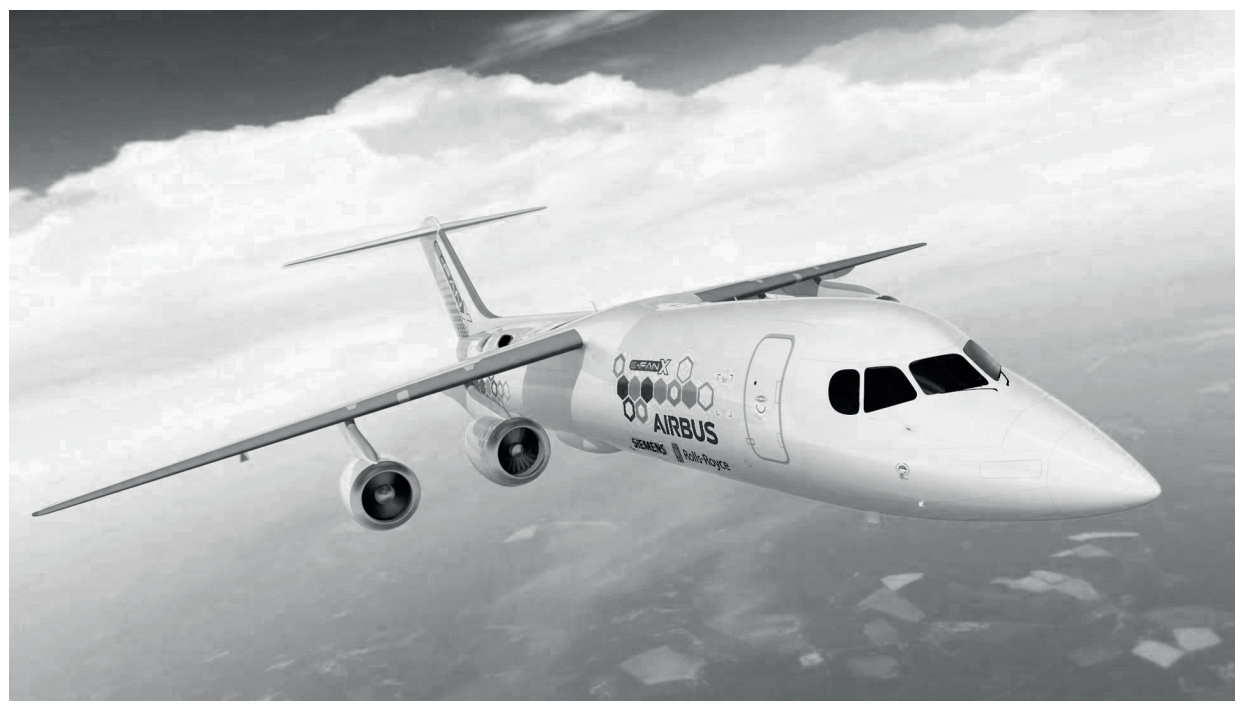

Figure 5. A visualization of Bae 146 aircraft equipped in E-Fan X motor Source: (http://airbus.com)

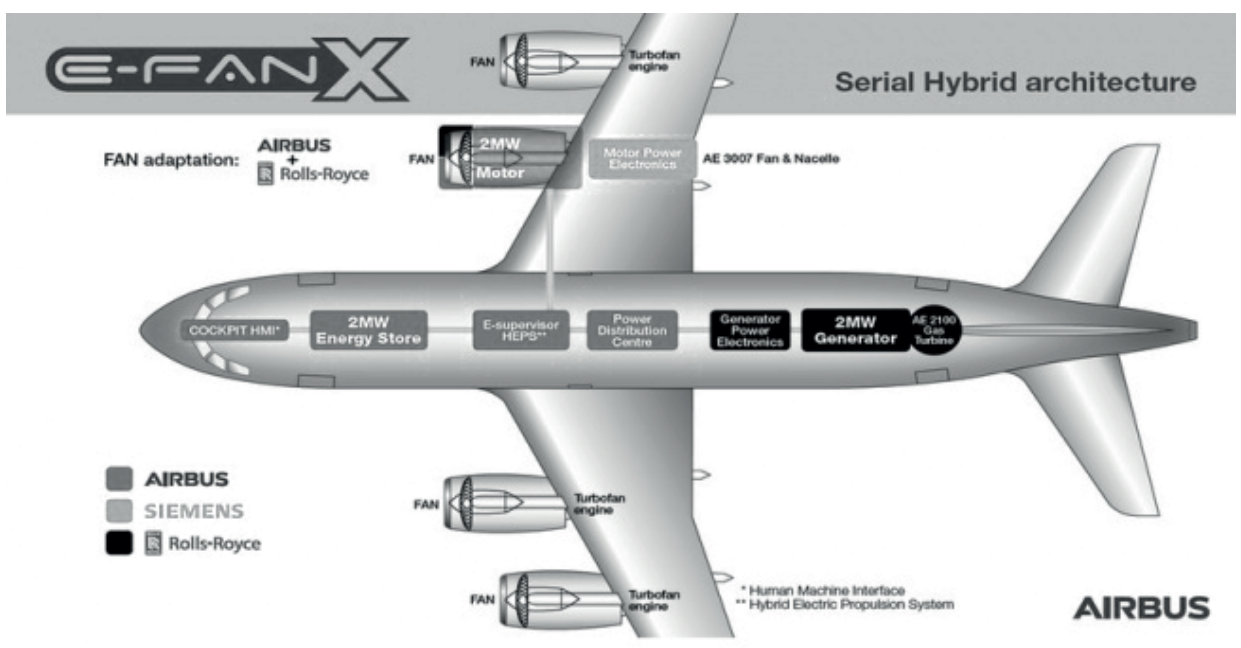

Figure 6. Architecture of an aircraft equipped in E-Fan X motor Source: (http://siemens.com)

The idea of a hybrid aircraft surely is innovative and will benefit the environment. However, one must be aware that there are advantages as well as disadvantages to this solution. Both, advantages and disadvantages are shown in Table 1. 
Table 1. Advantages and disadvantages of a hybrid aircraft

\begin{tabular}{|l|l|}
\hline \multicolumn{1}{|c|}{ Advantages } & \multicolumn{1}{c|}{ Disadvantages } \\
\hline $\begin{array}{l}\text { I. reduction of greenhouse gas emission } \\
\text { II. lower maintenance costs }\end{array}$ & $\begin{array}{l}\text { I. necessity of fleet modernization } \\
\text { III. noise reduction }\end{array}$ \\
$\begin{array}{l}\text { IV. reduction of conventional fuel consumption } \\
\text { III. small range }\end{array}$ & $\begin{array}{l}\text { IV. sensitivity to weather conditions } \\
\text { V. high costs of manufacturing and utilization } \\
\text { of electric components }\end{array}$ \\
\hline
\end{tabular}

Source: (own elaboration)

The biggest and the most important advantages from the EU's and environmental point of view are reduction of greenhouse gas and noise emission. It is expected that transforming air fleet from internal combustion to hybrid might decrease overall $\mathrm{CO}_{2}, \mathrm{NO}_{x}$ and $\mathrm{SO}_{x}$ emission by quarter, which gives about 38 million tons yearly in a global scale. And such result will be achieved by replacing only one combustion engine with an electric motor. Airbus' plans assume replacing two if the concept successfully comes into force. Noise emission is also a problem that needs to be solved. Noise made by a taking off jet aircraft reaches a number of about $95 \mathrm{~dB}$ and it has a negative impact on comfort and health of people living in areas a short distance away from airports. One idea stated in the European Commission's document An Aviation Strategy for Europe is to move people away from airports, but it's not always possible, especially when the airport is located in the city. The idea of a hybrid aircraft implies use of electric motors during take-off and landing, thereby the noise will be reduced when the plane is closest to human habitats. After reaching full altitude the plane would automatically switch to combustion engine. Such solution would also allow flying at night, since people wouldn't be exposed to trouble caused by the noise during airplane's take-off and landing.

Another advantage is reduction of conventional fuel consumption. If one combustion engine is replaced with a hybrid motor, fuel consumption will also drop by $1 / 4$, what in effect will lead to a decrease in greenhouse emission which is stated above. And, except for environmental benefits, reduction of fuel consumption has economic benefits for airline companies - they will buy $1 / 4$ less fuel, what will allow them to lower operating costs.

The last advantage, which is pointed out by Airbus, Rolls-Royce and Siemens themselves, are lower maintenance cost. They state that the electric motor in its final form will be less faulty and won't need to be serviced and replaced frequently.

However, despite significant advantages, the idea of a hybrid aircraft has also important disadvantages. The worst of them, from economic point of view and for passengers is the necessity of fleet modernization. Replacing an aircraft or at least engines in aircrafts in operation is associated with enormous costs. Even spreading the expense in time will put airlines in a difficult situation, and, as it's known, every cost airline has to bear is moved on passengers. So, the consequence of fleet replacement will be an increase in ticket prices.

Moreover, Airbus, Rolls-Royce and Siemens state that the main obstacle for E-Fan $X$ are weather conditions, as it is stated above. It means that electric components react badly to high altitude, changes in temperature and pressure. Long exposure 
to hostile weather conditions may cause systems to fail and greatly decrease airplane's safety level.

Last but not least, it is commonly known that electric means of transport are more expensive than the ones powered with fossil fuels. Such conditions result from higher costs of production of electric components. It also applies to air transport. Airplanes with electric drive will cost more than airplanes powered by combustion engines. Also when the component comes out of service, airlines will have to deal with high costs of utilization and strict standards in this regard.

\section{Conclusions}

Nowadays environmental protection is gaining importance and the European Union tightens provisions regarding emission of greenhouse gas and noise. Airlines and airplane manufacturing companies face a need to make air transport more environmentally-friendly. In these realities Airbus, Rolls-Royce and Siemens teamed up to develop an innovative idea of an electric motor and a hybrid aircraft. Although the concept is still in the phase of development, it already has high potential for the future. Such solution has its advantages, that mostly benefit the environment, so it fits in current trends. But the idea of a hybrid aircraft also has its disadvantages and these concern mostly the economic side of company's activity. In some time it may happen that air carriers and airplane manufacturers will have to decide whether they want to go more "green" or keep their high position on the market. However the question is how long will it take before air industry companies will be forced to obey the rules of environmental protection.

\section{References}

Airbus website, http://airbus.com.

Airbus, Rolls-Royce, Siemens (2017), Airbus, Siemens, and Rolls-Royce team up for electric future Partnership launches E-Fan X hybrid-electric flight demonstrator, Press release. Available from https://www.airbus.com/newsroom/press-releases/en/2017/11/airbus_rolls-royceand-siemens-team-up-for-electric-future-par.html.

European Commission (2015), Communication from the Commission to the European Parliament, the Council, the European Economic and Social Committee and the Committee of the Regions, An Aviation Strategy Europe, COM(2015) 598 final. Available from https://ec.europa.eu/ transparency/regdoc/rep/1/2015/EN/1-2015-598-EN-F1-1.PDF.

European Environment Agency (EEA) website, http://eea.europa.eu.

Eurostat website, http://ec.europa.eu/eurostat.

International Civil Aviation Organization (ICAO) website, http://icao.int.

Kotowska, I. (2014), Żegluga morska bliskiego zasięgu w świetle idei zrównoważonego rozwoju transportu, Wydawnictwo Naukowe Akademii Morskiej w Szczecinie, Szczecin.

Polskie Linie Lotnicze LOT website, http://lot.com.

Ruciński, A. (Ed.) (2008), Porty lotnicze wobec polityki otwartego nieba, Fundacja Rozwoju Uniwersytetu Gdańskiego, Gdańsk.

Siemens website, http://siemens.com. 
Tłoczyński, D. (2013), Światowy rynek transportu lotniczego w roku 2012: wybrane problemy i kierunki rozwoju, Zeszyty Naukowe Uniwersytetu Gdańskiego. Ekonomika Transportu $i$ Logistyka, 48, pp. 24-44.

\section{Corresponding author}

Natalia Drop can be contacted at: n.drop@am.szczecin.pl 